\title{
Psychoeducation on Reproductive Health as Self-protection from Sexual Violence for 5- to 6-year-old Children
}

\author{
Siska Konda A. Melontige ${ }^{a}$ \& Frieda Maryam Mangunsong ${ }^{b *}$ \\ ${ }^{a}$ Faculty of Psychology, Universitas Indonesia, Depok, Indonesia; ${ }^{b}$ Department of Educational \\ Psychology, Faculty of Psychology, Universitas Indonesia, Depok \\ *Corresponding Author: \\ Frieda M. Mangunsong \\ Educational Psychology Department \\ Faculty of Psychology, Universitas Indonesia \\ Jl. Lkr. Kampus Raya, Depok, Jawa Barat \\ Indonesia, 16424 \\ Tel.: +62 217270004 \\ E-mail: friemangun@gmail.com
}




\title{
Psychoeducation on Reproductive Health as Self-protection from Sexual Violence for 5- to 6-year-old Children
}

\begin{abstract}
This study aims to determine the effectiveness of a reproductive health psychoeducation program to enhance knowledge and ability of self-protection from sexual violence for children aged 5-6 years old. A total of 13 children participated in a reproductive health psychoeducation program using observational learning approach. Children's knowledge and ability to protect themselves from sexual violence were measured by sexual violence prevention knowledge, knowledge on appropriate and inappropriate touches, and ability to respond verbally and non-verbally. Research was conducted using before and after design. A statistical test using Wilcoxon signed rank shows a significant difference in three items being measured after intervention. This result means that the reproductive health psychoeducation program is effective to enhance knowledge on sexual violence prevention, improve the ability to recognize inappropriate touches, and increase the ability to respond verbally and non-verbally.
\end{abstract}

Keywords: child sexual abuse; observational learning; prevention; sex education; psychoeducation

\section{Introduction}

The number of child sexual abuse cases that occur in Indonesia has increased significantly. Data from Komisi Perlindungan Anak Indonesia (Commission for Child Protection, 2016) for the period 2011-2014 show that the number of children who were sexually abused has increased year by year. This number increased because of rape, violation, sodomy, pedophilia, and others. In 2011, a total of 216 cases were reported, which rose to 412 in 2012. In 2013, 343 cases of sexual violence against children happened, and in 2014, the number almost doubled to 656 cases.

The utilization of children as sexual objects has a spectrum of behavior that ranges from exposing private body parts to the child, touching unwanted body parts, and acts of rape (Stoltenborgh, van Ijzendoorn, Euser, \& Bakermans-Kranenburg, 2011 as cited in Walsh \& Brandon, 2012). Sexual violence has adverse effects on children, both in the short and long terms. Generally, perpetrators of sexual assault on children are those who are close to them and whom they trust. According to Brooks (2011), in addition to feeling physical pain, children who lose their trust in authority figures feel depressed. Children who are exposed to sexual violence experience physical, emotional, psychological, and social impairment (Brooks, 2009). Without proper intervention, the effects of sexual violence can hinder children's development and potentially make them adults with various emotional or mental disorders (Maniglio, in Perez, 2013).

The large number of cases of sexual violence against minors can be divided into groups who are at risk of experiencing sexual violence. Among these groups, preschool children are the most vulnerable (Berrick, 1991). Being dependent on adults in fulfilling their needs (Briggs \& Hawkins, 1987), preschool children are vulnerable to sexual abuse. This vulnerability may also be due to the lack of information given by adults to children. Cognitively, children aged 2-6 years begin to develop an understanding of the concept of self and are curious about their bodies, 
but adults (parents and educators) do not provide the necessary information on reproductive health. Adults still believe that reproductive health education for children is taboo, and some parents think that children will not understand such information (Briggs \& Hawkins, 1997). Further elaboration on reproductive health for children was stated in a regulation from the Minister of Education and Culture (Permendikbud) number 146, year 2014, under point Core Competencies (KI) and Basic Competence (KD) along with details of the indicator of development goals. Children's knowledge of reproductive health can be developed through an intervention psychoeducation program.

Psychoeducation on reproductive health is necessary because children's knowledge about sexual violence is limited (Daro, 1994). An effective way to educate preschool children is through a combination of modeling, discussion, and rehearsal (Topping \& Barron, 2009). Teaching through modeling on behavioral skills training as proposed by Wurtele and Owens (1997) achieved high results in knowledge acquisition about preventing sexual violence, the ability to recognize appropriate and inappropriate touch, and the ability to respond verbally and nonverbally as indicated by a group of program participants compared with a control group. Active participants reiterate that the modeled behavior yields better efficacy levels compared with that of participants who did not repeat the modeled behavior (Wurtele, Marrs, \& Miller-Perrin, 1987).

In Indonesia, Jatmikowati, Angin and Ernawati (2015) suggest using puppets, illustrations, and short films as tools to provide sex education to children. This proposal aims to address the issue that sensitive sexual material causes doubts on teachers' ability to explain the knowledge to preschool students. To avoid such doubts, teachers explain the material which is considered sensitive and taboo using symbolic modeling such as dolls, drawings and illustrations, and short films, which help in the delivery of sex-related education for early childhood.

The present study aims to increase knowledge about prevention of sexual violence and the ability of self-protection through a psychoeducation reproductive health program using symbolic modeling with dolls, drawings, books, poster images, or movies, as well as live modeling and active involvement of the participants (participant modeling) to reiterate the modeled behavior (active rehearsal). Learning by observation in the reproductive health program involves four observational learning processes, i.e., attention, retention, production, and motivation. The increase of knowledge and ability of self-protection is measured in this program based on three aspects: knowledge on the prevention of sexual violence, ability to recognize an appropriate and inappropriate touch, and ability of self-protection response with verbal and nonverbal signs. These three aspects are used as the measurement before intervention (pretest) and after intervention (post-test). This study expected psychoeducation reproductive health to be effective in increasing the knowledge on sexual violence and ability of self-protection in children aged 56 years.

One of the primary prevention strategies at the community level is conducted through psychoeducation. According to Nelson-Jones (as cited in Supratiknya, 2008), the academic approaches in teaching psychology are psychoeducation and experiential approach. Psychoeducation emphasizes the acquisition of knowledge through thinking skills, while the experiential approach emphasizes the creation of knowledge through experience (learning by doing). Material knowledge and capabilities delivered include recognizing components, namely, introduction of private body parts and how to protect them, and introduction of appropriate and inappropriate touch. The components teach a child the ability to report to a trusted adult about 
the inappropriate behavior of other adults such as touching and other acts that involve private body parts. Mastery of the material in psychoeducation reproductive health can be ensured through learning by observation (observational learning).

Observational learning is based on social cognitive theory introduced by Bandura (1974, 1989, as cited in Berns 2010) that individual learning occurs through observation of the behavior of others. In this model, individuals can learn new patterns of behavior through cognitive assessment with competency standards and establishment of general rules of conduct. In the observational learning approach, involvement of role models to be observed has an important role. Modeling allows an individual to learn social behavior, attitudes, and emotions experienced by himself/herself or others. To affect behavior, according to Bandura (1989, as cited in Berns, 2010), the modeling relies on a situation in which the active behavior is more likely to be imitated than passive behavior. The observer must be able to understand and remember the behavior and perform verbal and motor skills or engage in behavior that is modeled. Modeling that can be monitored include two types. The first type is live modeling, which can be observed and can display an alternative behavior or skill to the observer (Cartledge \& Milburn, 1995) in natural social situations. In this type of modeling, a model should have an important role for a child and should also be capable of being identified by children; examples are family members, caregivers, teachers, and peers. The second type is symbolic modeling, which is a representation of display behavior that can be observed through the characters in a story book, print media (magazines and newspapers), a puppet stage, and audio-visual material such as film (Cartledge \& Milburn, 1995).

Learning through symbolic modeling could be conducted by observing the behavior of a model or character in books, , or in movies and videos. Learning through observation (observational learning) involves several stages, namely, attention, retention, production, and motivation (Bandura, 1977). First, According to Bandura (1977), the individual cannot learn much by observation if he/she is unable to recognize the essential features of the behavior of the model. Thus, the selection model in the process of attention is an important element. Preference and suitability of the observer enables emulation compared with the different models of the observer. The model with pleasant qualities are interesting, while those that do not have pleasant characteristics tend to be ignored or rejected. The models delivered through television footage in the form of characters are effective in catching the attention of viewers, both children and adults, in the process of learning a behavior.

Second, in the process of retention, the individual is not significantly affected by the model behavior observed if he/she is unable to remember it. Memory of a modeled behavior stored in the form of symbols is represented in two systems, namely, imaginable and verbal representations. The resulting stimulation in modeling is achieved through sensory conditioning, which can survive in the form of an overview of the sequence of model behavior, which is then transformed into images and verbal symbols to make it easier to use. The symbolic code via imagination or an overview allows the person to exercise behavior in the form of thoughts without physically performing the behavior. In addition to symbolic codes, repetition or exercise is required to recall the modeled behavior. An observer's cognitive functioning is instrumental in processing the results of attention. When an object catches a person's attention strongly, it obtains a special code. The moral justification of a behavior occurs in the process of attention. A child who observes a behavior that is praised or rewarded will justify that such a behavior is morally right. However, if a behavior is punished, then the child will assess that such a behavior 
is wrong (Bandura, 1977). The information received and then stored cognitively will be called again when it is needed.

Third, production processes are associated with a symbolic representation of a process that turns into concrete action. An observer must be able to combine responses in accordance with the behavior modeled to achieve reproductive behavior. This ability is dependent on whether the individual has components of behavior. An observer who has all the elements or components of behavior would easily integrate it into new behavioral patterns, but if the observer lacks the necessary elements, then the reproduction behavior cannot occur. In this case, one should consider the return of the model and practice. A certain capability cannot be retrieved only from sheer observation but also through training.

Fourth, the process of motivation deals with the way to strengthen and encourage the behavior of children. Reinforcement occurs in the form of understanding the consequences of their behaviors and determines if vicarious behavior that has been retrieved will be used or not. Behavior that is formed will be reinforced with motivation. At this stage, locomotion or motion occurs, in which an individual has a strong urge to choose and perform an action.

\section{Methods}

\section{Participants}

The participants in this study were 13 kindergarten children (4 boys and 9 girls) aged 5-6 years from predominantly low-income families in North Jakarta. The researcher selected the preschool in this area on the basis of convenience method. Initial data retrieval (pretest) showed that 20 children participated in the entire program on the first day, but on the second and third days, the number of attendees varied because some children did not attend school and were unable to participate in the program. Due to the absence of some of the children, the number of participants decreased to 13 after the data retrieval program (post-test 1) and data retrieval two weeks after the program implementation (post-test 2). The treatment programs were led by the researcher and assisted by kindergarten teachers. Four graduate students conducted interviews to collect data.

\section{Research Design}

The design used in this study is before and after design (Kumar, 1996). According to Kumar (1996), this design is in accordance with the type of research that aims to measure the effectiveness of an intervention. Based on the data collected, the research design is referred to as pretest and post-test, with data retrieval conducted twice: before (pretest) and after (post-test) the intervention. Measuring the knowledge and abilities of participants consists of knowledge about prevention of sexual violence, ability to recognize appropriate and inappropriate touch, and ability of self-protection through verbal and nonverbal responses.

\section{Measures}

Measurements or data retrieval was conducted with interview techniques and instruments of data collection using the interview schedule, namely, Personal Safety Questionnaire (PSQ) (Wurtele, Kast \& Melzer, 1992 as cited in Zhang et al., 2013) and "What If" Situation Test (WIST) (Wurtele, Kast, Miller-Perrin \& Kondrick, 1989). PSQ is used to assess the knowledge of children about preventing sexual violence (Wurtele et al., 1992 as cited in Zhang et al., 2013). Four questions were used in the PSQ, specifically two questions to assess the knowledge of 
children about sexual violence and two questions to assess the child's behavior toward sexuality. PSQ measurements for data retrieval included "yes," "no," or "don't know" answers. The right answer is given a score of 1 , so the range of scores for the PSQ is 0-4.

WIST (Wurtele et al., 1989) was used to measure the ability of self-protection. WIST consists of six brief vignettes or scenarios, specifically three scenarios about the request to see and touch the private body part, and three scenarios on not allowing to see and touch the private body part. To measure or assess in WIST the child's ability to recognize if the request is inappropriate, children were asked, "Is it okay (in the scenario name) to (see or touch your private part)?" The correct answer was given a score of 1 and an incorrect or uncertain answer was given a score of 0 . Responses to this question generate a two-score assessment, namely, (1) a deserved demand is identified in WIST based on the ability to recognize the request (score range is $0-3$ ), and (2) the request identification WIST score is inappropriate (score range is $0-3$ ).

PSQ and WIST were adapted from the original sources and then tried with seven preschool children in another school in North Jakarta. The questionnaires were revised before they were used for the intervention in the group of children.

The measurement of children's knowledge and ability to prevent sexual violence is performed before the program intervention (pretest), immediately after the program intervention (post-test 1), and two weeks after the program intervention (post-test 2). Data acquisition from measurement is then analyzed statistically using the Wilcoxon signed ranks.

\section{Procedure}

According to the symbolic phase of cognitive learning of 5-6-year-old children, the technique used in this program included dolls, drawings, books, poster images, and movies as well as live modeling and active involvement of the participants (participant modeling) to reiterate the modeled behavior (active rehearsal). The intervention consisted of five sessions with observational processes that go through the stages of attention, retention, production, and motivation.

The procedures in this study begin with measurement before the intervention (pretest) and continue with the implementation of five intervention program sessions, each having a duration of 15-25 minutes, for three consecutive days. On the first day, the material is provided in two sessions that present the introduction of a private body (session 1) and how to protect personal body parts (session 2). On the second day, the material is presented in two sessions containing the introduction to appropriate and inappropriate touching (session 3), and the verbal and nonverbal responses to avoid and refuse and avoid inappropriate behavior (session 4). On the third day, the material provided a single session that contains a self-protection response by reporting verbally to trusted adults (session 5) and proceeds with the measurement immediately after the program intervention (post-test 1). Two weeks later, the program intervention conducted measurement again (post-test 2). 
Table 1.

\begin{tabular}{|c|c|c|}
\hline Session & Material Content & Observational Learning \\
\hline 1 & $\begin{array}{l}\text { Introduction of a } \\
\text { private body }\end{array}$ & $\begin{array}{l}\text { Attention stage: The researcher introduces the private parts of the body using dolls as models. } \\
\text { Retention stage: The teachers ask questions about the private parts. } \\
\text { Production stage: The participants point to and mention the four private parts of the body Motivation } \\
\text { stage: The researcher provides motivation so that participants can repeat the modeled behavior. }\end{array}$ \\
\hline 2 & $\begin{array}{l}\text { How to protect } \\
\text { personal body parts }\end{array}$ & $\begin{array}{l}\text { Attention stage: The researcher reads a picture story and explains the four private parts. } \\
\text { Retention stage: The researcher asks the participants to attach underwear and outerwear alternately on } \\
\text { the pictures of boys and girls on a poster. } \\
\text { Production stage: The participants are divided into four small groups and they identify the clothing } \\
\text { needed to protect the body. } \\
\text { Motivation stage: The researcher provides motivation to participants who have yet to exercise their } \\
\text { behavior. }\end{array}$ \\
\hline 3 & $\begin{array}{l}\text { Introduction of touch } \\
\text { (appropriate and } \\
\text { inappropriate) }\end{array}$ & $\begin{array}{l}\text { Attention stage: By using dolls as models, the researchers teach the participants not to undress and } \\
\text { show their private body parts to another person. } \\
\text { Retention stage: The researchers ask the participants questions, such as who may touch the body parts. }\end{array}$ \\
\hline 4 & $\begin{array}{l}\text { Verbal and nonverbal } \\
\text { response to refuse and } \\
\text { avoid inappropriate } \\
\text { touch }\end{array}$ & $\begin{array}{l}\text { Attention stage: The participants watch a video. } \\
\text { Retention stage: The participants are divided into four groups and then are asked to rearrange the } \\
\text { pictures in a particular order. } \\
\text { Production stage: The participants gather in large groups. The researcher asks for some participants to } \\
\text { stand in front of the class and repeat the behavior shown in the video animation. }\end{array}$ \\
\hline 5 & $\begin{array}{l}\text { Self-protection } \\
\text { response by reporting } \\
\text { verbally to trusted } \\
\text { adults }\end{array}$ & $\begin{array}{l}\text { Attention stage: The participants watch a video. } \\
\text { Retention stage: After watching the video animation, the participants are divided into four groups. In } \\
\text { each group, the teachers ask the participants what actions are performed by the characters in the video } \\
\text { to prevent adults from touching their private body parts. } \\
\text { Production stage: In the small group, the teacher asks the participants alternately, repeating the } \\
\text { behavior as modeled in the video animation to prevent adults from touching the private body parts. } \\
\text { Motivation stage: The teacher fixes the less stages that have not been done by the participants and } \\
\text { provide motivation to the children to repeat the modeled behavior. }\end{array}$ \\
\hline
\end{tabular}

\section{Result}

The results obtained from measurement of children's knowledge about prevention of sexual violence are reported in Table 2.

Table 2.

Test results show the Wilcoxon signed rank test and statistical test knowledge of children regarding the prevention of sexual violence

\begin{tabular}{|c|c|c|c|c|c|c|}
\hline \multirow[t]{2}{*}{ Ranks in post-test 1 and pretest } & & & \multicolumn{4}{|c|}{ Ranks in post-test 2 and post-test 1} \\
\hline & $\mathrm{N}$ & Mean & Sum of & $\mathrm{N}$ & Mean & Sum of \\
\hline & & Rank & Ranks & & Rank & Ranks \\
\hline Negative Ranks & 1 & 2.50 & 2.50 & 3 & 2.50 & 7.50 \\
\hline Positive Ranks & 8 & 5.31 & 42.50 & 3 & 4.50 & 13.50 \\
\hline Ties & 4 & & & 7 & & \\
\hline Total & 13 & & & 13 & & \\
\hline Statistical test: post-test 1 and pretest & & & & \multirow{3}{*}{\multicolumn{3}{|c|}{$\begin{array}{l}\text { Statistical test: post-test } 2 \text { and post-test } 1 \\
-0.649 \\
0.516\end{array}$}} \\
\hline $\mathrm{Z}$ & -2.412 & & & & & \\
\hline Asymp. Sig. (two-tailed) & 0.016 & & & & & \\
\hline
\end{tabular}

Table 2 shows a significant difference between post-test 1 and the pretest on children's knowledge about prevention of sexual violence. Although the results of the statistical tests between post-test 2 and post-test 1 do not show the existence of differences, we can infer that the knowledge on preventing sexual violence obtained from psychoeducation reproductive health 
programs did not exhibit a difference of two weeks after administering the program. The score is the same as in post-test 1 , which shows an increase from the pretest.

Table 3.

Wilcoxon signed rank test and statistical test results of children's ability to recognize an appropriate touch

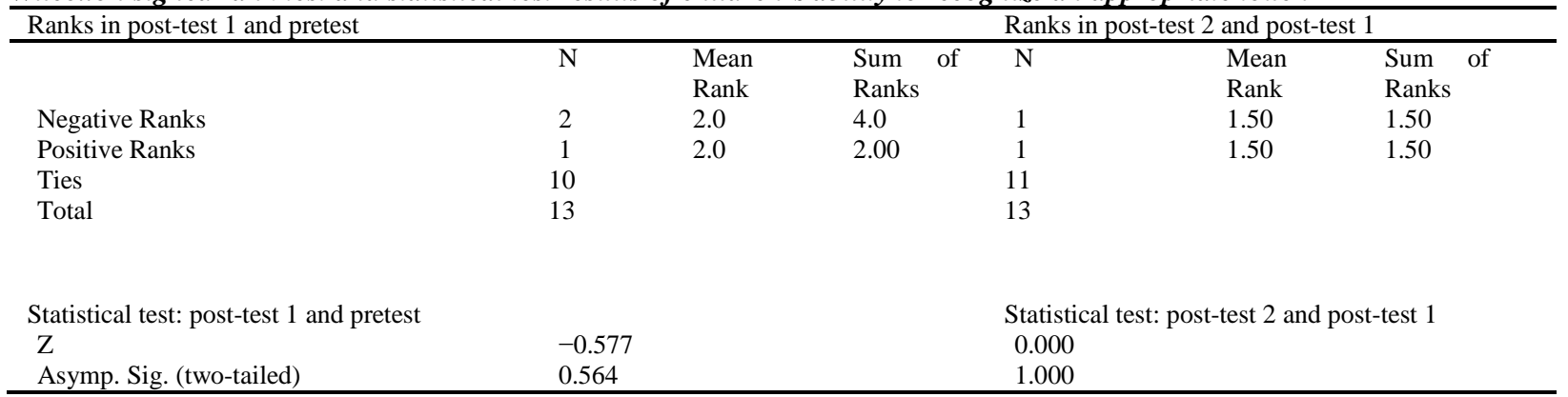

The table ranks show no significant difference between post-test 1 and the pretest, so we can conclude that the program on reproductive health psychoeducation does not provide a statistically significant difference in the child's ability to recognize an appropriate touch before and after the intervention. The table shows that even before the intervention, the children already recognized what touch was appropriate or inappropriate. Meanwhile, the results of the statistical tests between post-test 2 and post-test 1 show no significant difference. We can conclude that two weeks after the program, the child's ability to recognize an appropriate touch, as obtained from reproductive health psychoeducation, did not exhibit any difference.

Table 4.

Wilcoxon signed rank test and statistical test results of children's ability to recognize inappropriate touch

\begin{tabular}{|c|c|c|c|c|c|c|}
\hline \multirow[t]{3}{*}{ Ranks in post-test 1 and pretest } & & & \multicolumn{4}{|c|}{ Ranks in post-test 2 and post-test 1} \\
\hline & $\mathrm{N}$ & Mean & Sum of & $\mathrm{N}$ & Mean & Sum of \\
\hline & & Rank & Ranks & & Rank & Ranks \\
\hline Negative Ranks & 1 & 4.0 & 4.0 & 3 & 4.83 & 14.50 \\
\hline Positive Ranks & 7 & 4.57 & 32.00 & 5 & 4.30 & 21.50 \\
\hline Ties & 5 & & & 5 & & \\
\hline Total & 13 & & & 13 & & \\
\hline Statistical test: post-test 1 and pretest & & & & \multirow{2}{*}{\multicolumn{3}{|c|}{$\begin{array}{l}\text { Statistical test: post-test } 2 \text { and post-test } 1 \\
-0.513\end{array}$}} \\
\hline $\mathrm{Z}$ & -1.982 & & & & & \\
\hline Asymp. Sig. (two-tailed) & 0.047 & & & 0.608 & & \\
\hline
\end{tabular}

The table ranks show a significant difference between post-test 1 and the pretest, so we can conclude that the reproductive health psychoeducation program provides a statistically significant difference in children's ability to recognize inappropriate touch before and after the intervention. Although the results of the statistical tests between post-test 2 and post-test 1 have no significant difference, we can conclude that two weeks after the grant program, the child's ability to recognize inappropriate touch, as obtained from the psychoeducation program, remains the same. 
Table 5.

Comparison of Wilcoxon signed rank test and statistical test results of self-protection response

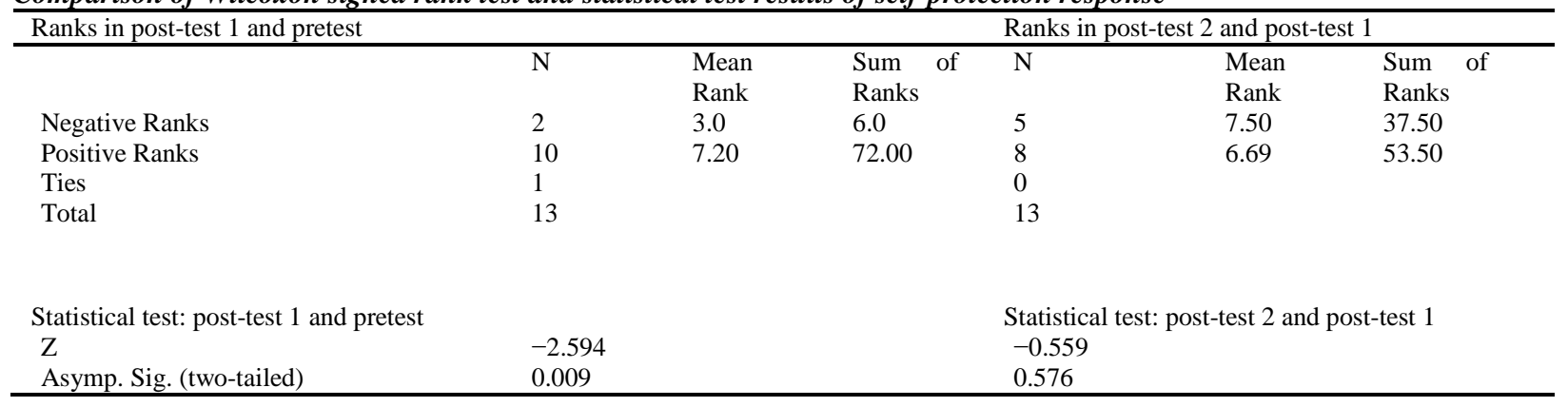

The table ranks shows a significant difference between post-test 1 and the pretest, so we can conclude that the psychoeducation program provides a statistically significant difference in the ability in self-protection response before and after the intervention.

Although the results of the statistical tests between post-test 2 and post-test 1 exhibit no significant difference, we can conclude that two weeks after the program, the children's ability in self-protection response, as obtained from the psychoeducation program on reproductive health, did not change.

\section{Discussion}

This study concludes that the reproductive health psychoeducation program increased the participants' knowledge about the prevention of sexual violence and ability of self-protection response. The effectiveness of the program was determined from the difference in mean values significantly between pretest and post-test 1, with the post-test 1 average score greater than that of the pretest, and a significant difference was observed in the statistical test results for the three items. Only the ability to recognize an appropriate touch showed no difference in the pretest and post-test scores. The results of the statistical tests showed no difference in data before and after the intervention. After two weeks, the acquisition of knowledge on the prevention of sexual violence, the ability to recognize inappropriate touch, and the ability of self-protection response, remained the same.

The knowledge of the participants on the prevention of sexual violence increased after the interventions. This result suggests that symbolic modeling is effective in teaching the concept of sexual violence rather than learning in abstract terms (Conte, Rosen, Saperstein, \& Shermack, 1985). These results are similar to suggestions from previous findings by Jatmikowati, Angin, and Ernawati (2015) that the use of symbolic modeling, such as dolls, pictures, and short films, is beneficial to highlight the information about sensitive and taboo material for early childhood. After intervention, an increase was also observed in the ability to respond verbally and nonverbally because the video animation presented the stages of self-protection response clearly and sequentially so that they could be emulated by the participant. In addition, the process of production in this study allows the participant to repeat the modeled behavior.

Another factor that influenced the success of this intervention is the congruency between the characteristics of the participants and those in the symbolic modeling used in the study, such as 
dolls, picture story books, posters, and video animation, which involved figures of a teacher, a mother, children, life, and environment in accordance with the children's cognitive development.

Some of the participants showed a decline in knowledge and ability because of the production session, in which some participants were passive and less able to perform the behavior repetition they learned from the intervention. Mostly, the result remained the same, with an increase in the score from the pretest to post-test 1. In the process of motivation, the researcher provided inducement or words to encourage the participants to repeat the behavior. However, the participants who did not have the opportunity to repeat the modeled behavior cannot develop the required behavior as expected. The decrease in the participants' knowledge and ability was due to their inconsistent attendance during the program intervention. Thus, the participants did not obtain the information and instructions necessary to enhance their knowledge and ability (Santrock, 2006). Teachers who were not consistent in exemplifying the behavior also caused a decrease in the ability of the participants. The acquisition of knowledge and ability of selfprotection response remained the same two weeks after intervention because of the repetition of the modeled behavior in the production process and strengthened the memories of the participants (Conte, Rosen \& Saperstein, 1986).

This study has limitations, such as in the production process in which some of the children were passive and incapable of repeating the modeled behavior even though they were being encouraged to do so. The children who did not consistently participate did not have enough knowledge and ability to remember the information given, and had limitations in practicing the proper behavior strategy, including obtaining feedback from symbolic and live modeling. Furthermore, during data retrieval, the interviews were conducted in the main room with the door open and the room was the only access path into the restroom. Thus, the teachers and children often crossed the main room and the implementation of the pretest and post-test was interrupted by voices outside. Other distractions also occurred when friends of the participants sat next to them during the interview process.

Suggestions to improve this study program include integrating psychoeducation reproductive health into everyday teaching and learning activities. Thus, the participants will have an opportunity to repeat the lessons when necessary. Furthermore, this program should be administered to a larger number of participants. Psychoeducation on reproductive health should be communicated to parents who can explain the reproductive health experience to their children. Parents can discuss the subject with their children at home using scientific language without vulgarity.

\section{References}

Andin, S.N. (2013). Program individual untuk meningkatkan self-efficacy dalam membaca bacaan berbahasa Inggris pada siswa sekolah dasar melalui modelling dan attributional retraining. Master's Thesis. Universitas Indonesia, Depok.

Bandura, A. (1977). Social Learning Theory. New Jersey: Prentice-Hall, Inc.

Berns, R. M. (2010). Child, family, school, community, socialization and support. International Edition. Wadsworth. USA.

Berrick, J. \& Barth, R. (1992). Child sexual abuse prevention-research review and recommendation. http://escholarship.org/uc/item/8h8527qs

Briggs, F. \& Hawkins, R. (1997). A child protection: A guide for teachers and child care professionals. Australia: Allen \& Unwin

Brooks, J. (2011). The process of parenting (8th ed.). New York, NY: McGraw-Hill International Edition

Cartledge, G. \& Milburn, J. F. (1995). Teaching social skill to children and youth (3rd ed.). Massachusetts: Allyn and Bacon. 
Conte, J. R., Rosen, C., \& Saperstein. L. (1986). An analysis of programs to prevent the sexual victimization of children. Journal of Primary Prevention, 6, 141-155.

Conte, J. R., Rosen, C., Saperstein, L., \& Shermack, R. (1985). An evaluation of a program to prevent the sexual victimization of young children. Child Abuse and Neglect. 9, 319-328.

Daro, D. A. (1994).Prevention of child sexual abuse. The Future of Children Sexual Abuse of children, 4 (2), 198-223.

Indonesia's Commissions for Child Protection (2016).Kebijakan perlindungan anak dari kekerasan seksual. Disampaikan pada Seminar Series: membangun peneliti, pelaku dan praktisi perlindungan anak masa depan, Dep kriminologi FISIP UI Depok.

Islawati, I., \& Paramastri, I. (2015).Program “jari peri” sebagai pelindung anak dari kekerasan seksual. Jurnal Psikologi 42, 2, $115-128$.

Jatmikowati, T.E., Angin, R. \& Ernawati. (2015). Model dan materi pendidikan seks anak usia dini perspektif gender untuk menghindarkan sexual abuse. Cakrawala Pendidikan, Thn. XXXIV, No. 3

Kementerian Pendidikan dan Kebudayaan Republik Indonesia. (2015). Peraturan Menteri Pendidikan dan Kebudayaan (Permendikbud) Nomor 146 tahun 2014 tentang kurikulum 2013 pendidikan anak usia dini.

Kumar, R. (1996). Research Methodology. London: Sage Publication.

National Center on Child Abuse and Neglect.(1978). Child sexual abuse: Incest, assault, and sexual exploitation, a special report. Washington, DC: Author.

Papalia, D.E., Martorell, G. (2014).Experience human development. New York, NY: McGraw Hill.

Perez, C. (2013). Child safety: parent-children sexual abuse prevention program a grant proposal (Order No. 1524149). Available from ProQuest Dissertations \&Theses Global. (1449380344). http://search.proquest.com/docview/1449380344? accountid=17242

Santrock, J.W. (2006).Life-span development $\left(10^{\text {th }}\right.$ ed).New York, NY: McGraw Hill.

Supratiknya, A. (2008). Merancang Program danModul-Psikoedukasi. Yogyakarta: Universitas Sanata Dharma.

Topping, K.J. \& Baron, I.G. (2009). School-based child sexual abuse prevention programs: a review of effectiveness. Review of Educational Research, 79 (1), 431-463. Doi 10.3102/0034654308325582.

Walsh, K.,\& Brandon, L. (2012). Their children's first educators: parent's views about child sexual abuse prevention program. Journal Child Family Study, 21,734-746. Doi 10.1007/s10826-011-9526-4

Wurtele, S. K., Kast, L. C., Miller-Perrin, C., \& Kondrick, P. A. (1989).Comparison of programs for teaching personal safety skills to preschoolers. Journal of Consulting and Clinical Psychology, 57(4), 505-511. doi:http://dx.doi.org/10.1037/0022006X.57.4.505

Wurtele, S. K., Marrs, S. R., \& Miller-Perrin, C. (1987). Practice makes perfect? the role of participant modeling in sexual abuse prevention programs. Journal of Consulting and Clinical Psychology, 55(4), 599-602. doi:http://dx.doi.org/10.1037/0022006X.55.4.599

Wurtele, S.K. \& Owens, J.S. (1997). Teaching personal safety skills to young children: an investigation of age and gender across five studies. Child Abuse \& Neglect, 21 (8), 805-814.

Zhang, W., Chen, J., Feng, Y., Li, J., Liu, C., \& Zhao, X. (2013).Evaluation of a sexual abuse prevention education for Chinese preschoolers. Research on Social Work Practice2014, Vol. 24(4) 428-436. Doi: 10.1177/1049731513510409 